\title{
Technical note \\ A new method for the determination of water quality
}

\author{
Karolina Jezierska*, Bolesław Gonet, Wojciech Podraza and Hanna Domek
}

Department of Medical Physics, Pomeranian Medical University, ul. Ku Słońcu 12, 71-075 Szczecin, Poland

\begin{abstract}
The aim of this study was to develop and test a novel screening method for determining water quality. We hypothesised that L-ascorbic acid would be a good indicator of water quality, due to its sensitivity to pollutants. We investigated the absorption spectra of L-ascorbic acid dissolved at different concentrations in water from different sources. We defined a water quality index (WQI) as the change in maximum L-ascorbic acid absorbance at $265 \mathrm{~nm}$ over two arbitrarily chosen time periods, i.e. between the $1^{\text {st }}$ and $10^{\text {th }}$ minutes and $1^{\text {st }}$ and $20^{\text {th }}$ minutes. We found that a high WQI value was significantly associated with low water quality, and vice versa. The proposed technique is a quick, simple and inexpensive method for obtaining a preliminary estimate of water quality.
\end{abstract}

Keywords: water quality, L-ascorbic acid, spectrophotometric method

\section{Introduction}

Access to safe water is a fundamental need and basic human right (WHO, 2000). Water is an indispensable component of the human body. Water also plays an important role in many branches of industry (cosmetics, food, pharmaceutical) and science. The quality of water is crucial, for example, in high performance liquid chromatography (Mabic et al., 2005). It is also a good solvent and main transporter of wide variety of chemical substances. Unfortunately, these properties heighten water's exposure to various kinds of pollution. Consequently, it is important to constantly protect and control the quality of water, particularly in regions with a deficiency of freshwater; for example, freshwater quality is a major concern in Africa (WHO, 2000; Mamba et al., 2009; Lobanga et al., 2009). However, even when water is plentiful, it is reasonable to verify the quality of drinking water, due to its large impact on our health.

Often tap water does not meet the required health criteria. This may be due to the poor condition of water pipes in the distribution system. High quality plumbing is essential for minimising water losses and ensuring an efficient, safe supply of water (Lobanga et al., 2009). The purity of water is also a significant factor in the economy and in agriculture (Blignaut and Van Heerden, 2009). For example, poor water quality affects the quality of crops (Ratajkiewicz, 2007; Woźnica and Waniorek, 2008).

There is no single definition of water quality, because it depends on the intended use of the water. There are many methods for determining water quality (Dojlido and Zerbe, 1998); each measures a specific parameter of water, and methods differ in precision, speed, and cost. Frequently, water quality determination is expensive and complicated. In this paper a new screening method that can provide a preliminary test of water quality is proposed. It is based on measuring the maximum absorbance of L-ascorbic acid (Vitamin C) in an aqueous solution.

\footnotetext{
* To whom all correspondence should be addressed.

용 +48 91 4414522; fax: +48 91 4414521; e-mail: karo@sci.pam.szczecin.pl

Received 19 May 2010; accepted in revised form 13 December 2010.
}

L-ascorbic acid is very important, both for the human body and in industry (cosmetics, food, and pharmaceutical products) (Farris, 2005; Wójtowicz, 2008; Kopera and Mitek, 2006; Pierzynowska et al., 2007; Touitou et al., 1996). Previous studies have showed that Vitamin $\mathrm{C}$ has another, new application, in the determination of water quality. In solution, L-ascorbic acid absorbs UV light with a maximum absorption in the 246$268 \mathrm{~nm}$ wavelength range. Vitamin $\mathrm{C}$ is quite water soluble, but, in aqueous solution, it is unstable (Touitou et al., 1996), with high sensitivities to UV light and temperature (both high and low). The quality of the solvent also influences the speed of Vitamin $\mathrm{C}$ degradation. For example, the presence of ions, like $\mathrm{Fe}, \mathrm{Mg}, \mathrm{Cu}$, or $\mathrm{Ni}$, can increase the degradation rate of ascorbic acid (Deutsch, 1998; Davey et al., 2000; Jian-Ping and Feng, 1998). Thus, the rapidity of degradation due to specified factors ( $\mathrm{pH}$, temperature, and concentration) depends on the water quality. This reasoning prompted us to create a new screening test for water quality. This study aimed to develop and validate this novel water screening test.

\section{Methods}

The absorption spectra of L-ascorbic acid in different aqueous solutions were investigated, with a PHARO (Merck Sp. z o.o, Warszawa, Poland) spectrophotometer. Vitamin C was supplied by POCH (Polskie Odczynniki Chemiczne, Gliwice, Poland). Water was obtained from 6 different sources, including de-ionised water from the Department of Experimental and Clinical Pharmacology PAM (Sample 1), tap water from the Department of Medical Physics (Sample 2), filtered tap water from the latter source, using a new Brita filter (Sample 3), filtered tap water from the latter source, with a used $(360 \ell)$ Brita filter (Sample 4), 'Kropla Beskidu' mineral water (Sample 5), and 'Kryniczanka' mineral water (Sample 6). For preliminary tests, different amounts of Vitamin C $(1,5$, and $10 \mathrm{mg})$ were dissolved in each water sample $(100 \mathrm{~m} \ell)$. We measured 3 Vitamin $\mathrm{C}$ concentrations in order to determine the peak sensitivity of the method. Five absorbance measurements were performed on each solution, for a total of 90 measurements. Samples of L-ascorbic acid at $1 \mathrm{mg} / 100 \mathrm{~m} \ell$ were tested in $10 \mathrm{~mm}$ quartz cuvettes; samples at 5 and $10 \mathrm{mg} / 100 \mathrm{~m} \ell$ were tested in 


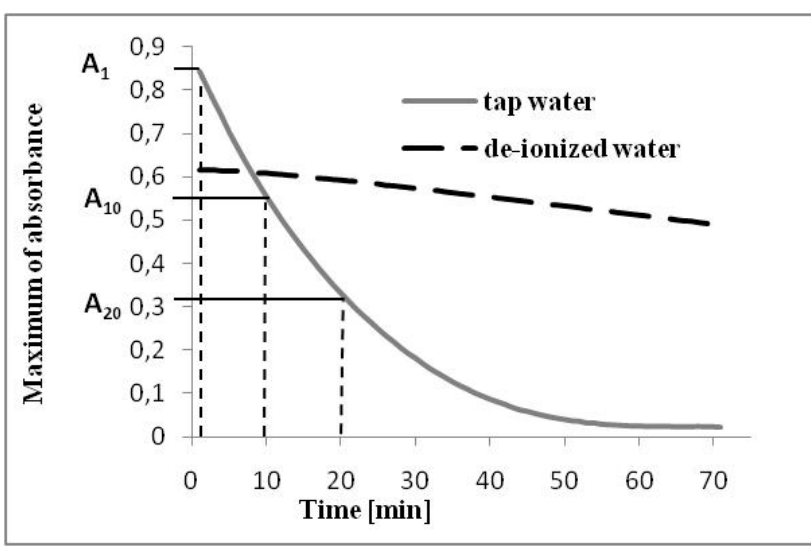

Figure 1

Decrease of maximum absorbance at $265 \mathrm{~nm}$ for L-ascorbic acid in tap and de-ionised water (for concentration $1 \mathrm{mg} / 100 \mathrm{ml}$ ). Measurement times are indicated with dashed vertical lines at $1^{\text {st }}, 10^{\text {th }}$ and $20^{\text {th }}$ minutes.

$1 \mathrm{~mm}$ quartz cuvettes. Changes in the absorbance at $265 \mathrm{~nm}$ were recorded over 10 and $20 \mathrm{~min}$. The water quality index (WQI) was defined as the speed of decreasing of absorbance of Vitamin C:

$$
\begin{aligned}
& \mathrm{WQI}_{(10)}=\mathrm{A}_{1}-\mathrm{A}_{10} \\
& \mathrm{WQI}_{(20)}=\mathrm{A}_{1}-\mathrm{A}_{20}
\end{aligned}
$$

where:

$A_{1}, A_{10}, A_{20}$ were the absorbances at the $1^{\text {st }}, 10^{\text {th }}$ and $20^{\text {th }}$ minutes, respectively.

Normality of data distribution was checked by the ShapiroWilk test. Where data were shown to be normally distributed, statistical analysis using the Student's t-test was performed, otherwise the Mann-Whitney U-test was performed (Statistica; $p<0.05)$.

\section{Results}

The UV absorption spectra were obtained for all L-ascorbic acid solutions. An example of the rate at which maximum L-ascorbic acid $(1 \mathrm{mg} / 100 \mathrm{~m} \ell)$ absorbance decreased over time is presented in Fig. 1. The mean WQI ${ }_{(10)}$ and $\mathrm{WQI}_{(20)}$ values for

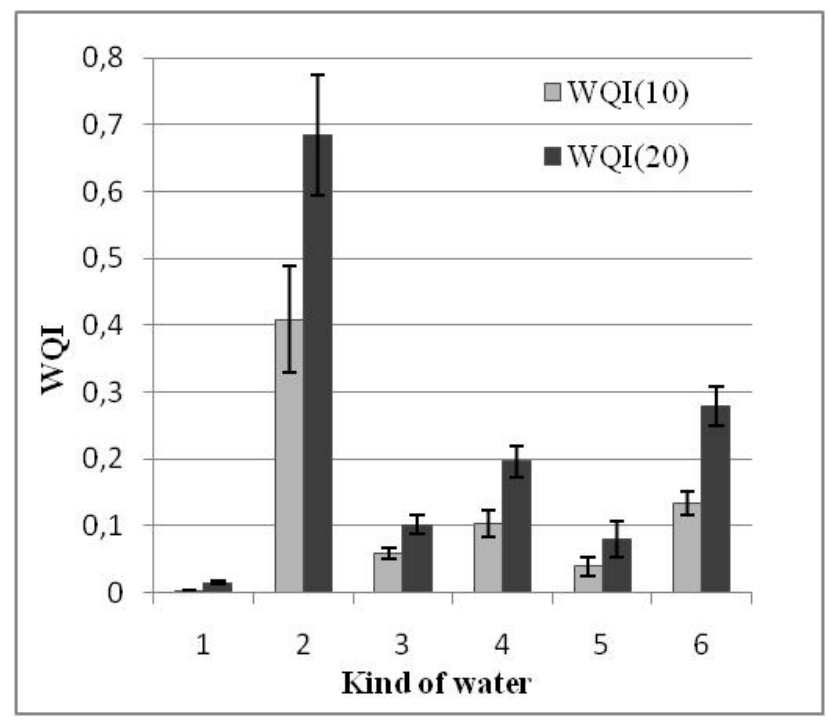

Figure 2

Average WQI ${ }_{(10)}$ and WQI ${ }^{20)}$ values for $L$-ascorbic acid samples dissolved in water from different sources. Averages are shown for 5 replicated measurements; error bars indicate standard errors. Water samples were:

- De-ionised water (1)

- Tap water (2)

- Tap water filtered with a new filter (3)

- Tap water filtered with a used filter (4)

- 'Kropla Beskidu' mineral water (5)

- 'Kryniczanka' mineral water (6)

all samples are presented in Fig. 2. The $p$-values for comparing different samples over both measurement time periods are presented in Table 1.

\section{Conclusions}

In this study, we developed a simple, inexpensive, sensitive spectrophotometric method for determining water quality. This is a quick method ( $20 \mathrm{~min}$ ) for making a preliminary estimate of the quality of any kind of water. Most laboratories possess the required equipment for this application.

Our results showed that a high WQI indicated low water quality and vice versa. Water quality was significantly cor-

\begin{tabular}{|c|c|c|c|c|}
\hline \multicolumn{5}{|c|}{$\begin{array}{c}\text { Table } 1 \\
\text { Comparisons of water from different sources. } \\
\text { Water sources included de-ionised water (1), tap water (2), tap water filtered with a new } \\
\text { filter (3), tap water filtered with a used filter (4), 'Kropla Beskidu' mineral water (5), and } \\
\text { 'Kryniczanka' mineral water (6). The differences between the indicated samples are shown } \\
\text { with } p \text { values, based on the change in maximum absorbance of } 1 \mathrm{mg} / 100 \mathrm{m \ell} \text { of L-ascorbic } \\
\text { acid over the indicated time periods. }\end{array}$} \\
\hline \multirow{3}{*}{$\begin{array}{l}\text { Samples } \\
\text { compared } \\
(1 \mathrm{mg} / 100 \mathrm{~m} \ell)\end{array}$} & \multicolumn{4}{|c|}{ Time range } \\
\hline & \multicolumn{2}{|c|}{$W \mathbf{I}_{(10)}$} & \multicolumn{2}{|c|}{$W_{(20)}$} \\
\hline & t-test & U Mann-Whitney & t-test & $\begin{array}{c}\text { Mann-Whitney } \\
\text { U-test }\end{array}$ \\
\hline 1 vs. 2 or 3 or 6 & & $p<0.05$ & $p<0.05$ & \\
\hline 1 vs. 5 & & $p<0.05$ & & $p<0.05$ \\
\hline 2 vs. 3 or 5 & & $p<0.05$ & $p<0.05$ & \\
\hline 2 vs. 6 & & $p<0.05$ & & $p<0.05$ \\
\hline 3 vs. 4 & & $p<0.05$ & & $p<0.05$ \\
\hline 5 vs. 6 & $p<0.05$ & & & $p<0.05$ \\
\hline
\end{tabular}
related to the change in maximum L-ascorbic acid absorbance 
$(p<0.05)$. The kinetics of the deterioration reaction were not investigated, as this was beyond the scope of this study. The major disadvantages of the method is its non-specificity exactly which pollutants react with ascorbic acid is unknown. Thus, it is necessary to investigate further and the proposed technique should merely be considered as a preliminary screening test.

Our results indicate that a concentration of $1 \mathrm{mg} / 100 \mathrm{~m} \ell$ and a measurement time range of 20 min provided the greatest differences between water samples. Thus, these parameters are recommended for obtaining maximum sensitivity with this method. At higher concentrations, the differences between samples were less distinct, because the capacity of the pollutants was saturable. Therefore, we propose that this technique should be performed with $1 \mathrm{mg} / 100 \mathrm{~m} \ell$ concentration of L-ascorbic acid and measured for the $1^{\text {st }}$ to $20^{\text {th }}$ minute time range. This procedure should be repeated in other laboratories, in case of potentially slight differences in spectrophotometers.

The objective of measurements is to determine the average change in the maximum L-ascorbic acid absorbance for solvent (water) with the appropriate quality for the chosen application. Then, the average change of absorbance (WQI) of the standard can be compared to that of the water of unknown quality. A positive test (higher value of WQI) without doubt proves the presence of pollution in investigated water, a negative test doesn't exclude the possibility of the presence of pollutants which don't react with Vitamin C. Obviously, there is no universal method which can detect all pollutants. Temperature and $\mathrm{pH}$ can influence the test (in higher temperatures ascorbic acid is more unstable and location of maximum of absorption of Vitamin $\mathrm{C}$ in solutions with different $\mathrm{pH}$ values could be slightly different); thus, all measurements should be performed under the same conditions.

We propose the following applications for this novel water quality test:

- A water screening test, to ensure that distilled water installations are working properly; this is a very important facility in most laboratories

- A method for determining the turnover rate of domestic water filters

- A verification that mineral water standards are maintained by producers

- A method for checking the condition of a plumbing system that supplies clean water

\section{References}

BLIGNAUT J and VAN HEERDEN J (2009) The impact of water scarcity on economic development initiatives. Water $S A 35$ (4) 415-420.
DAVEY MW, MONTAGU MV, INZE D, SANMARTIN M, KANELLIS A, SMIRNOFF N, BENZIE IJJ, STRAIN JJ, FAVELL D and FLETCHER J (2000) Review plant L-ascorbic acid: chemistry, function, metabolism, bioavailability and effects of processing. J. Sci. Food Agric. 80 825-860. http://www3.interscience.wiley. com/cgi-bin/fulltext/72503927/PDFSTART

DEUTSCH JC (1998) Spontaneous hydrolysis and dehydration of dehydroascorbic acid in aqueous solution. Anal. Biochem. 260 223-229.

DOJLIDO J and ZERBE J (1998) Instrumental methods for testing water and wastewater. Arkady (in Polish) [Is this a journal article? If so, please give vol and page numbers, if a book, please give publisher and addresss]

FARRIS PK (2005) Topical Vitamin C: useful agent for treating photoaging and other dermatologic conditions. Dermatol. Surg. 31 814-818.

JIAN-PING Y and FENG C (1998) Degradation of ascorbic acid in aqueous solution. J. Agric. Food Chem. 46 5078-5082.

KOPERA M and MITEK M (2006) Effect of addition L-ascorbic acid in pulp on polyphenols content in pears juices. Żywność. Nauka. Technologia. Jakość. 2 (47) 116-123. (in Polish). URL: http://www. pttz.org/zyw/wyd/czas/2006.\%202(47)\%20Supl/13 Kopera.pdf

LOBANGA KP, VAN ZYL JE and ILEMOBADE AA (2009) The extent of non-compliant plumbing components used in South Africa. Water SA 35 (2) 175-182.

MABIC S, REGNAULT C and KROL J (2005) The misunderstood laboratory solvent: reagent water for HPLC. LCGC N. Am. 23 (1) 74-82. URL: http://chromatographyonline.findanalytichem.com/ $\underline{\mathrm{lcgc} / \mathrm{data} / \mathrm{articlestandard} / / \mathrm{lcgc} / 022005 / 141429 / \text { article.pdf }}$

MAMBA BB, KRAUSE RW, MATSEBULA B and HAARHOFF J (2009) Monitoring natural organic matter and disinfection byproducts at different stages in two South African water treatment plants. Water SA 35 (1) 121-127.

PIERZYNOWSKA J, PRĘDKA A, DYRWIEŃ M and OSTROWSKA $\mathrm{K}$ (2007) Comparision of vitamin C content in selected fresh and fermented vegetable juices. Bromat. Chem. Toksykol. XL 4 341-344 (in Polish). http://www.ptfarm.pl/pub/File/wydawnictwa/ b4 07/s\%20341-344.pdf

RATAJKIEWICZ H (2007) An influence of quality of water on the selected properties of tank mixes. Prog. Plant Prot. 47 (1) $115-$ 118 (in Polish). URL: http://www.progress.plantprotection.pl/ pliki/2007/1-1/47-1-1\%20(17).pdf

TOUITOU E, ALKABES A, MEMOLI A AND ALHAIQUE F (1996) Glutathione stabilizes ascorbic acid in aqueous solution. Int. J. Pharm. 133 (1996) 85-88.

WHO (World Health Organization) (2000) Global Water Supply and Sanitation Assessment 2000 Report. World Health Organization, Geneva. URL: http://www.who.int/docstore/water sanitation health/Globassessment/GlobalTOC.htm.

WOŹNICA Z and WANIOREK W (2008) Importance of water conditioners for glyphosate efficacy. Prog. Plant Prot. 48 (1) 329-335 (in Polish). URL: http://www.progress.plantprotection.pl/ pliki/2008/48-1-69.pdf

WÓJTOWICZ A (2008) Influence of ascorbic acid addition on texture of extruded precooked pasta. Acta Agrophysica 12 (1) 245-254 (in Polish). URL: http://www.acta-agrophysica.org/artykuly/acta agrophysica/ActaAgr $1612008 \quad 12$ 1 245.pdf 
Available on website http://www.wrc.org.za ISSN 0378-4738 (Print) = Water SA Vol. 37 No. 1 January 2011 